\title{
Significance of drones in monitoring of agricultural lands of Uzbekistan
}

\author{
Aziz Inamov ${ }^{1, *}$, Sanjarbek Safayev $^{2}$, and Shakhnoza Mukhammadayubova ${ }^{3}$ \\ ${ }^{1}$ Tashkent Institute of Irrigation and Agricultural Mechanization Engineers, Kari Niyazi str., 39, \\ Tashkent, 100000, Uzbekistan \\ ${ }^{2}$ State Scientific Research and Design Institute on Land Management "Uzdavyerloyiha", Choponota \\ str., Chilanzar-C massif, Tashkent, 100097, Uzbekistan \\ ${ }^{3}$ Tashkent Institute of Irrigation and Agricultural Mechanization Engineers, Kari Niyazi str., 39, \\ Tashkent, 100000, Uzbekistan
}

\begin{abstract}
Software of Geographic Information Systems (GIS) has been widely used for land evaluation and detection of changes in land area. Using GIS it is possible now to combine different environmental, social, economic data, which in turn leads to lower costs and allows collecting and processing a variety of data with the exact calculation of the required results necessary for land use. Therefore, research has been focused on remotely controlled devices. The research has been conducted to simplify the land record keeping (land inventory) system and to improve land monitoring methods using remote-controlled devices. As a result, economic efficiency and productivity have been increased.
\end{abstract}

\section{Introduction}

Uzbekistan has made great progress in the efficient use of land resources, their regulation, the use of aerial photos and satellite images in scientific research. Nowadays, through the use of innovative technologies, each industry is developing rapidly and achieving great success [1,9-11].

As it is generally known, until now, the work on updating or creating agricultural maps has been carried out using monochromatic analog aerial photographs. This situation has led to the following inconveniences in the creation of orthophotomaps in the republic:

- monochromeness of aerial photographs (colorless);

- high costs of surveying the area (air plane, fuel and etc.);

- a lot of time spent on camera work (geographic non-connection of the images, outdated software, etc.);

- a lot of manual labor;

- a lot of time and money spent on linking the plan and elevation coordinates.

Land inventory requires taking into account extensive studies of the infrastructure and economic status of the studied area. Certainly, efficient use of land is impossible without taking into account the socio-economic state of the land $[1,2,12]$. Although theoretically

\footnotetext{
* Corresponding author: aziz.inamovg@gmail.com
} 
there is potential for a particular use in any area, its implementation can be difficult. Hence, in addition to the ecological potential of the region, it is necessary to use the socioeconomic potential of a particular region $[1,13]$. On the other hand, lack of necessary knowledge about the rational use of land in people leads to a further reduction in the use of land resources $[3,4]$. The role of the unmanned aircraft in this regard is invaluable.

At present, unmanned aircraft is brought to Uzbekistan by the Committee "Davergeodezkadastr" (now the Cadastre Agency) on the order of the government and used by system organizations to perform a wide range of tasks. The flight of unmanned aircraft shall be carried out in special areas for the flight of aircraft in accordance with the legislation. Flight control of unmanned aircraft is carried out by the State Inspectorate for Flight Safety of the Republic of Uzbekistan [13-15].

Unmanned aircraft have a number of advantages not only in taking aerial photos but also in the chemical protection of plants [1].

Advantages of agro-drones:

- the density of the field soil layer will not increase, the crop will not be trampled;

- the harvest, branches and elements of crops will not be damaged;

- artificial spread of crop diseases will be prevented;

- convenience for processing fruit trees will be created;

- it is considered convenient to process the areas unreachable from the ground using aircraft and wind sprayers.

As a result, the use of unmanned aircraft in agriculture allows creation of an electronic map of the field by automatically taking aerial photographs, as well as automatic data processing, inspection of agricultural crops, evaluation of work performed and control over their implementation, operational monitoring of crop conditions, agricultural crop yields control, control of the germination of agricultural crops and checking the quality of land plowing [15]. The scientific novelty of the research is to improve the methods of geophysical binding of space data obtained by drones and the transformation of aerial photographs, the development of a sequence of cartographic projections in the creation of electronic digital maps and the development of digital models of land inventory.

\section{Materials and methods}

The methods such as remote sounding, monitoring, geophysical linking of objects, photogrammetric transformation of bitmaps, cartographic marking and digitization of information, processing of crops with the help of agro-drones, with cotton wind sprayer devices (CWS) and aircraft, unmanned aircraft for cartography (large-scale drawing and updating of maps), monitoring (inspection of agricultural crop lands), close-up imaging (in the implementation of internal land management on the farm), functions of unmanned aircraft in agriculture, on-site inspection and survey of lands, identification of lands in a difficult reclamation condition, to carry out agro-technical measures in land use at the level required by law in the process of research [16-18].

Another innovative technology for updating (creating) electronic digital maps is KOMSAT 3, bought from a Korean company, which was widely used in the creation of orthophotomaps images from satellite KOMSAT 3A, decoding of orthophotomaps in cameras and in the field conditions. Positive results were achieved in Pakhtakor and Dustlik districts of Jizzakh province using this unmanned aircraft. Photoplans were created using innovative technologies, and decoding was performed in camera and field conditions in Pakhtakor and Dustlik districts of Jizzakh province. District land users were inserted into prepared photoplans to legal documents with existing boundaries (inter-farm land management projects, district duty map). 


\section{Results and discussion}

The following information on land category was identified on land categories of Jizzakh province as of January 1, 2019: total seated land makes 2,117,830.0 hectares, of which irrigated land makes 300,355.0 hectares. Total amount of plowed land is 480,800.0 hectares; including irrigated sowing land 260,734.0 hectares, rainfed plowed lands $220,066.0$ hectares. Total amount of perennial groves is 18,502.0 hectares, of which gardens 12,110.0 hectares; vinegroves 4,002.0 hectares, mulberry groves 2,169.0 hectares, nursery-gardens makes 220.0 hectares (Fig. 1).

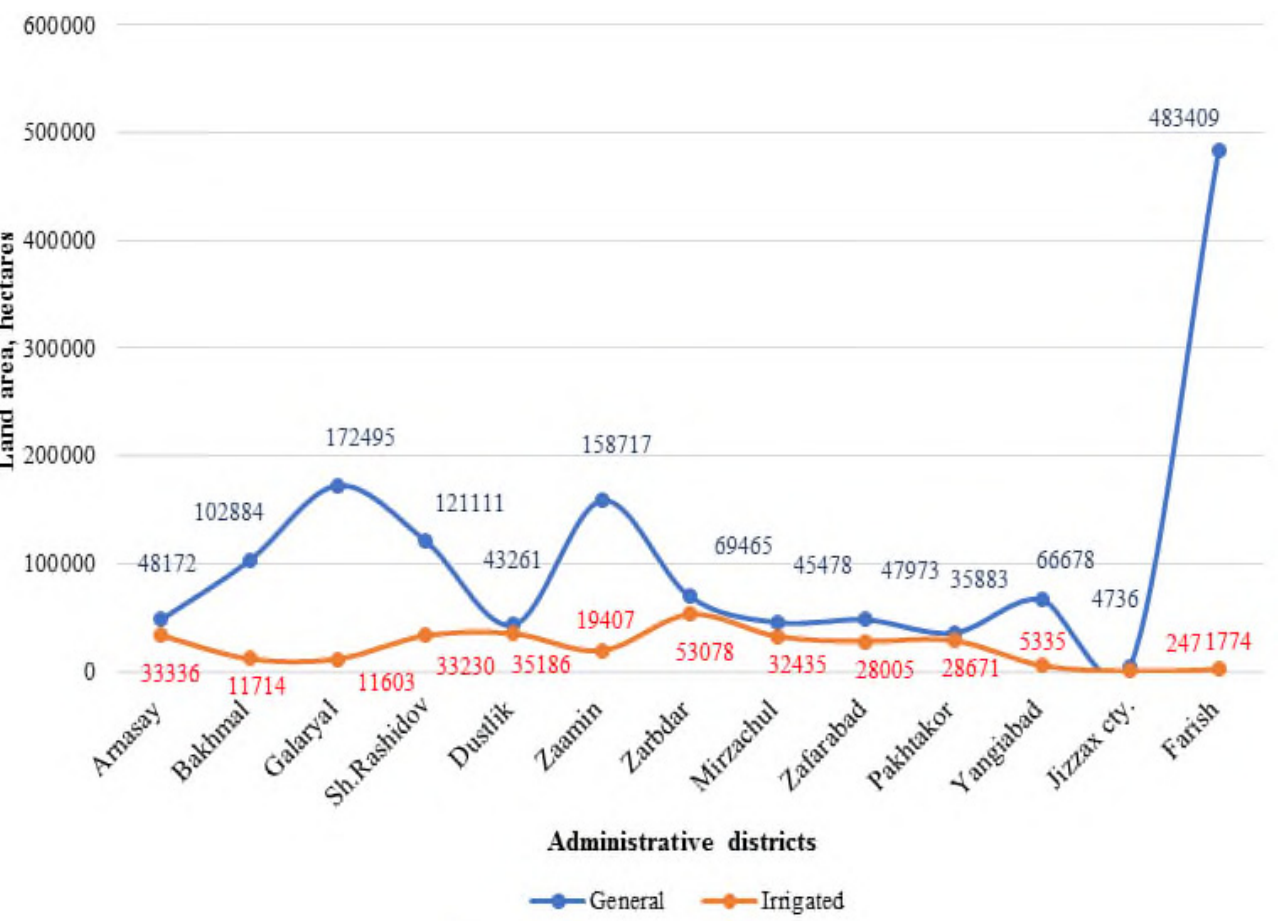

Fig. 1. Dynamics of total are of the land of agricultural designation in Jizzakh province.

Even if the total amount of land to be plowed has increased by $0.5 \%$, the amount of crop land to be watered has decreased by $0.72 \%$, arid crop land has increased by $1.95 \%$. Groves have increased in total by $10.64 \%$, of which gardens by $11.4 \%$, vinegroves have increased by $14.85 \%$, mulberry grove have decreased by $0.82 \%$, orchards have increased by $5.17 \%$ (Fig. 2 ).

Intensively irrigated agricultural lands of Jizzakh province make up 479,552 hectares or $34.24 \%$ of the total land area. Irrigated arable lands are considered the golden pool of our state, and all scientific, technical, economic and organizational opportunities are aimed at improving the condition of these lands, increasing their productivity (Fig. 3 and Table 1). 


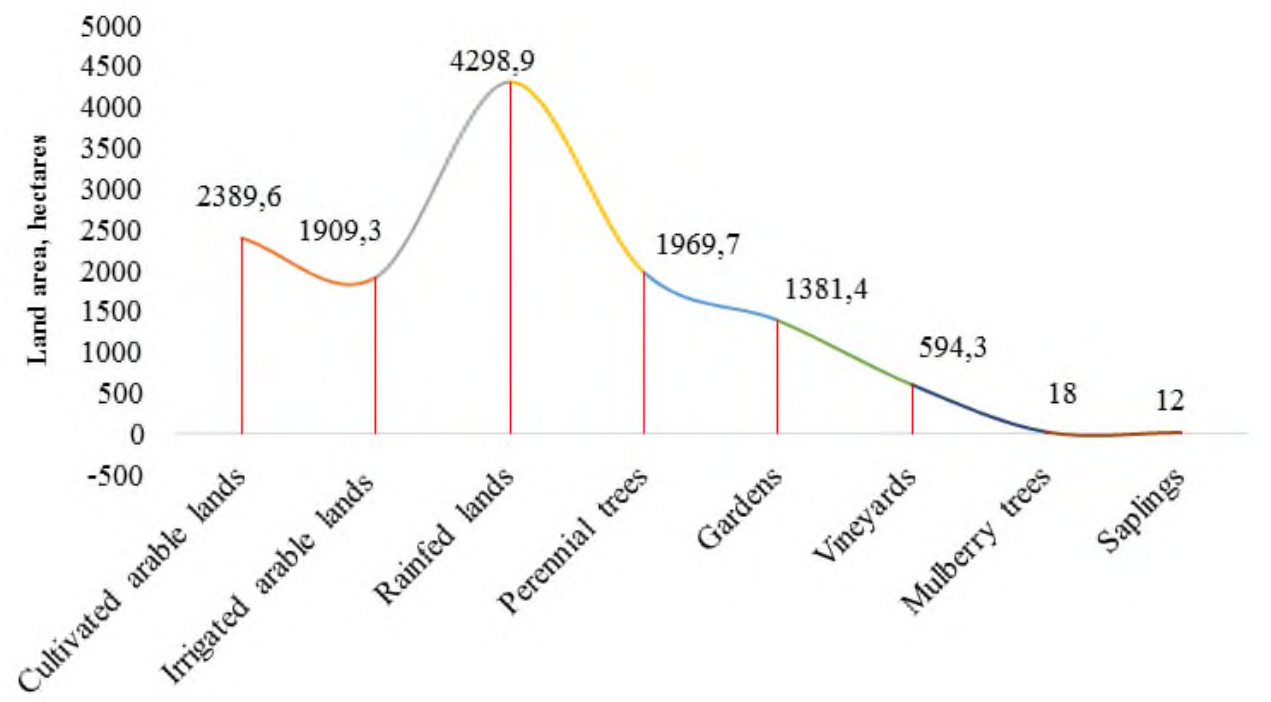

Fig. 2. Dynamics of total are of the land of agricultural designation in Jizzakh province.

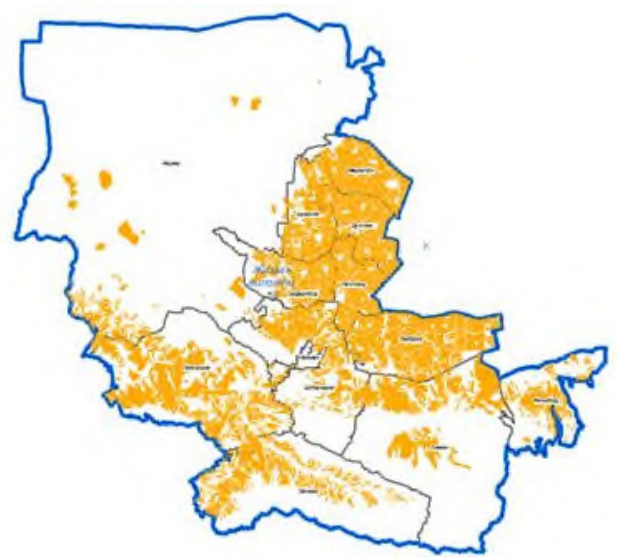

A) Used in agricultwe

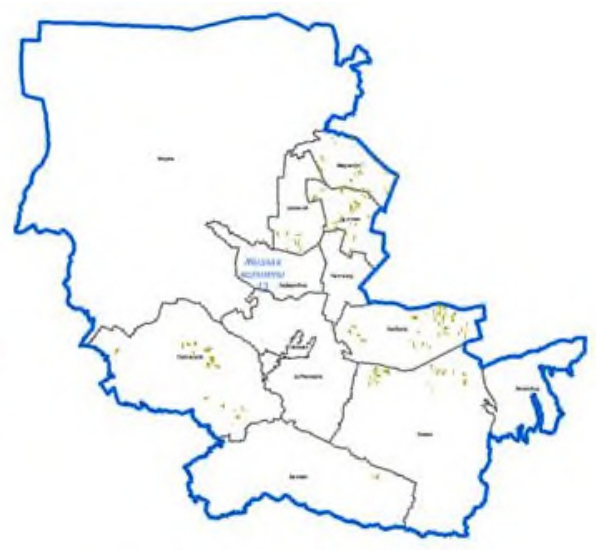

B) Agricultural enterprises and organizations

Fig. 3. Scheme of visualization of agricultural land in Jizzakh province in the geological data.

The comparison of the results of ground measurements has been performed using the An-2 aircraft and unmanned aerial vehicles. As it is known, if 50 hectares of land is studied by means of the of the air plane in 10 hours, when the usage of unmanned aircraft allows to obtain the required results by spending 2 hours on the same amount of work.

Field research was carried out in collaboration with specialists of the Jizzakh branch of the State Scientific Design Institute "Uzdaverloyiha". Besides, the results were widely used in the monitoring of agricultural lands. Has been developed a monitoring and creating a cartographic basis of agricultural land using remote control devices (Fig. 4 and Table 2) [17-19]. 
Table 1. Distribution of land type in the section of districts of Jizzakh province.

\begin{tabular}{|c|c|c|c|c|c|c|c|c|c|c|c|c|c|c|}
\hline \multirow{2}{*}{ 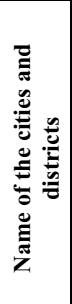 } & \multicolumn{2}{|c|}{$\begin{array}{l}\text { Total land } \\
\text { area }\end{array}$} & \multicolumn{2}{|c|}{$\begin{array}{l}\text { Cultivated } \\
\text { lands }\end{array}$} & \multicolumn{2}{|c|}{$\begin{array}{c}\text { Perennial } \\
\text { groves }\end{array}$} & \multicolumn{2}{|c|}{$\begin{array}{c}\text { Gray } \\
\text { soils }\end{array}$} & \multicolumn{2}{|c|}{$\begin{array}{l}\text { Hayland } \\
\text { and } \\
\text { pastured }\end{array}$} & \multicolumn{2}{|c|}{$\begin{array}{l}\text { Types od } \\
\text { agricultural } \\
\text { land }\end{array}$} & \multicolumn{2}{|c|}{$\begin{array}{c}\text { Landscaping } \\
\text { and } \\
\text { horticultural } \\
\text { vegetable } \\
\text { association } \\
\text { lands } \\
\end{array}$} \\
\hline & 气ूँ & : & हूँ & . & 吾 & 苞 & $\stackrel{\frac{\pi}{g}}{\frac{g}{3}}$ & 苞 & 至 & . & 跑 & D. & 急 & \\
\hline 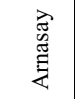 & 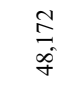 & 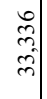 & $\frac{\stackrel{n}{g}}{m}$ & 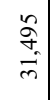 & 胥 & $\vec{F}$ & ' & & 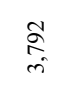 & & $\begin{array}{l}\infty \\
\stackrel{2}{2} \\
n \\
m\end{array}$ & $\begin{array}{l}\stackrel{0}{\circ} \\
\stackrel{m}{m}\end{array}$ & సু & నี \\
\hline 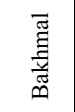 & 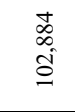 & $\stackrel{ \pm}{=}$ & $\begin{array}{l}\infty \\
0 \\
\text { in } \\
m\end{array}$ & $\begin{array}{l}\vec{n} \\
n \\
m\end{array}$ & 递 & $\begin{array}{l}\text { ot } \\
\text { in }\end{array}$ & $\begin{array}{l}\overrightarrow{\mathrm{B}} \\
\mathrm{i}\end{array}$ & & $\begin{array}{l}0 \\
: \\
\infty \\
\infty \\
\infty\end{array}$ & & $\begin{array}{c}\hat{b}_{2} \\
\aleph_{\infty} \\
\infty\end{array}$ & $\begin{array}{l}\text { in } \\
\text { to } \\
\infty\end{array}$ & 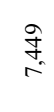 & $\begin{array}{l}\vec{D} \\
\substack{\infty \\
i}\end{array}$ \\
\hline 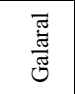 & 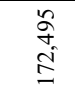 & $\begin{array}{l}\stackrel{0}{0} \\
\stackrel{0}{=}\end{array}$ & 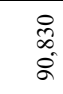 & 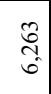 & 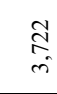 & $m_{m}^{n}$ & $\stackrel{\Omega}{I}$ & ڤे & $\begin{array}{l}\text { â } \\
\text { ît }\end{array}$ & & $\begin{array}{l}0 \\
\infty \\
\infty \\
\vdots \\
\vdots \\
\end{array}$ & \begin{tabular}{l}
\multirow{J}{J}{} \\
$\infty$ \\
$\sigma$ \\
$\sigma$
\end{tabular} & $\begin{array}{l}\vec{n} \\
m \\
m\end{array}$ & $\begin{array}{l}\infty \\
\stackrel{\infty}{0} \\
-\end{array}$ \\
\hline 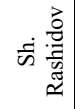 & $\begin{array}{l}\Xi \\
\vec{\Xi}\end{array}$ & 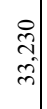 & 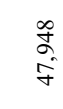 & $\begin{array}{l}\hat{\partial} \\
\hat{\alpha} \\
\hat{i}\end{array}$ & $\stackrel{\infty}{n}$ & $\stackrel{\infty}{\vdots}$ & $\stackrel{m}{2}$ & $\stackrel{\infty}{\circ}$ & $\begin{array}{l}\text { ì } \\
\text { aे }\end{array}$ & & $\begin{array}{l}\frac{m}{0} \\
\dot{0}\end{array}$ & $\begin{array}{l}\hat{\hat{S}} \\
\text { oे }\end{array}$ & है & $\stackrel{\tilde{s}}{i}$ \\
\hline 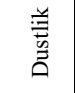 & $\begin{array}{l}\vec{b} \\
\text { f } \\
\text { f }\end{array}$ & $\begin{array}{c}\infty \\
\infty \\
m \\
m\end{array}$ & 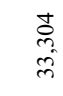 & 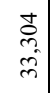 & 守 & in & , & & ' & & $\begin{array}{l}\hat{\alpha} \\
\infty \\
\hat{m}^{-}\end{array}$ & 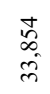 & $\stackrel{\circ}{\overrightarrow{0}}$ & $\underset{\infty}{\mathcal{\infty}}$ \\
\hline $\begin{array}{l}\text { 表 } \\
\text { 㷼 }\end{array}$ & 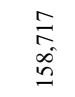 & $\begin{array}{l}\hat{q} \\
\stackrel{q}{a} \\
a\end{array}$ & $\begin{array}{l}\bar{\sigma} \\
\vec{\delta} \\
i n\end{array}$ & $\begin{array}{l}\tilde{\sigma} \\
\tilde{g} \\
\underline{0}\end{array}$ & s. & $\underset{-}{F}$ & $\begin{array}{l}\mathscr{b} \\
m\end{array}$ & & 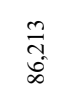 & & 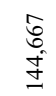 & $\begin{array}{l}\hat{\Omega} \\
\tilde{\Xi}\end{array}$ & $\frac{\pi}{m}$ & $\stackrel{\text { I }}{-}$ \\
\hline 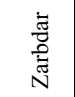 & $\begin{array}{l}2 \\
b \\
o \\
0 \\
0\end{array}$ & 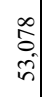 & $\begin{array}{l}\hat{\hat{y}} \\
\text { है } \\
\text { î }\end{array}$ & $\begin{array}{l}q \\
q \\
g \\
g\end{array}$ & s̊ & $\hat{\sigma}$ & I & $\stackrel{゚}{\beth}$ & 点 & & $\begin{array}{l}\overrightarrow{\vec{\sigma}} \\
\text { ì }\end{array}$ & $\begin{array}{l}\text { ते } \\
\text { है } \\
\text { in }\end{array}$ & $\underset{4}{7}$ & $\begin{array}{l}0 \\
\text { à } \\
\text { in }\end{array}$ \\
\hline $\begin{array}{l}\bar{\Xi} \\
\stackrel{\Xi}{\mathscr{g}} \\
\stackrel{\Xi}{\Sigma}\end{array}$ & \begin{tabular}{l}
$\infty$ \\
\multirow{f}{f}{} \\
$\mathfrak{f}$
\end{tabular} & $\begin{array}{l}n \\
\tilde{q} \\
i \\
\tilde{m}\end{array}$ & 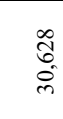 & $\begin{array}{l}8 \\
q \\
0 \\
0 \\
0\end{array}$ & $\stackrel{\infty}{\infty}$ & $\stackrel{\tilde{D}}{\curvearrowright}$ & $\stackrel{\tilde{v}}{\sim}$ & & $\begin{array}{c}\infty \\
+\infty \\
\text { के }\end{array}$ & & 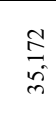 & $\stackrel{\tilde{\infty}}{\vec{m}}$ & $\bar{\infty}$ & $\stackrel{m}{2}$ \\
\hline 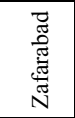 & $\begin{array}{l}\hat{2} \\
\hat{\sigma} \\
\hat{\sigma}\end{array}$ & $\begin{array}{l}n \\
\vdots \\
o \\
o \\
c\end{array}$ & 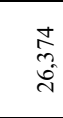 & 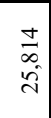 & $\frac{n}{6}$ & $\frac{n}{6}$ & ' & & $\begin{array}{l}\text { हुे } \\
\text { + }\end{array}$ & & $\begin{array}{l}\infty \\
\infty_{0} \\
= \\
m\end{array}$ & $\begin{array}{l}\stackrel{a}{\infty} \\
\stackrel{+}{+} \\
\text { in }\end{array}$ & $\stackrel{m}{m}$ & $\stackrel{E}{\hat{S}}$ \\
\hline 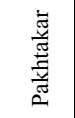 & $\begin{array}{l}\infty \\
\infty \\
\infty \\
\hat{n}^{2}\end{array}$ & $\begin{array}{l}\vec{b} \\
0 \\
0 \\
d\end{array}$ & $\begin{array}{l}\text { aे } \\
\text { ते }\end{array}$ & $\begin{array}{l}\hat{a} \\
\hat{i} \\
\hat{i}\end{array}$ & ปै & Iี & ' & & ' & & $\begin{array}{l}\vec{f} \\
\stackrel{\vec{w}}{\sim}\end{array}$ & $\begin{array}{l}\vec{J} \\
\stackrel{2}{N}\end{array}$ & है & f \\
\hline 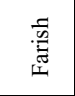 & 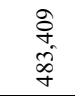 & $\stackrel{+}{\stackrel{t}{\Xi}}$ & 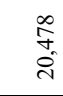 & $\stackrel{n}{F}$ & ন & $\stackrel{\hat{\infty}}{2}$ & مَ & & $\begin{array}{l}\text { 声 } \\
\text { 总 } \\
\text { di }\end{array}$ & & $\begin{array}{l}\vec{\infty} \\
\infty \\
\infty \\
\infty \\
\infty\end{array}$ & ते & $\begin{array}{l}\infty \\
\infty \\
i \\
i\end{array}$ & f \\
\hline 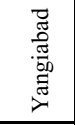 & 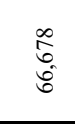 & m. & 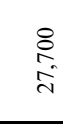 & $\begin{array}{l}\hat{\sigma} \\
\dot{m}\end{array}$ & $\frac{7}{6}$ & $\frac{n}{n}$ & $\stackrel{\circ}{n}$ & & $\begin{array}{l}: \\
\stackrel{0}{ \pm} \\
\dot{f}\end{array}$ & & के & $\begin{array}{l}\frac{t}{n} \\
\dot{v}\end{array}$ & $\stackrel{\infty}{\infty}$ & $\underset{\infty}{\stackrel{\infty}{\triangleright}}$ \\
\hline 总 & 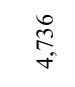 & 竎 & $\overbrace{-\infty}^{\infty}$ & $\stackrel{\infty}{\sigma}$ & c) & $\ddot{d}$ & 1 & & مे & & लె & $\hat{\Omega}$ & $\stackrel{q}{\mathcal{F}}$ & $\stackrel{\infty}{+}$ \\
\hline 吾 & 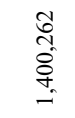 & $\begin{array}{l}\overrightarrow{\widehat{c}} \\
\overrightarrow{0} \\
\vec{i}\end{array}$ & 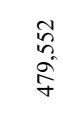 & $\begin{array}{l}n \\
\hat{n} \\
2 \\
n \\
n\end{array}$ & $\begin{array}{l}\widehat{2} \\
\substack{\infty \\
\infty}\end{array}$ & तु & $\begin{array}{c}0 \\
0 \\
0\end{array}$ & 8 & 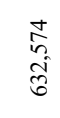 & & 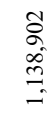 & 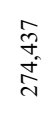 & $\begin{array}{l}\stackrel{+}{0} \\
\stackrel{+}{+} \\
\stackrel{\sim}{\sim}\end{array}$ & $\begin{array}{l}20 \\
\infty \\
n \\
n\end{array}$ \\
\hline
\end{tabular}



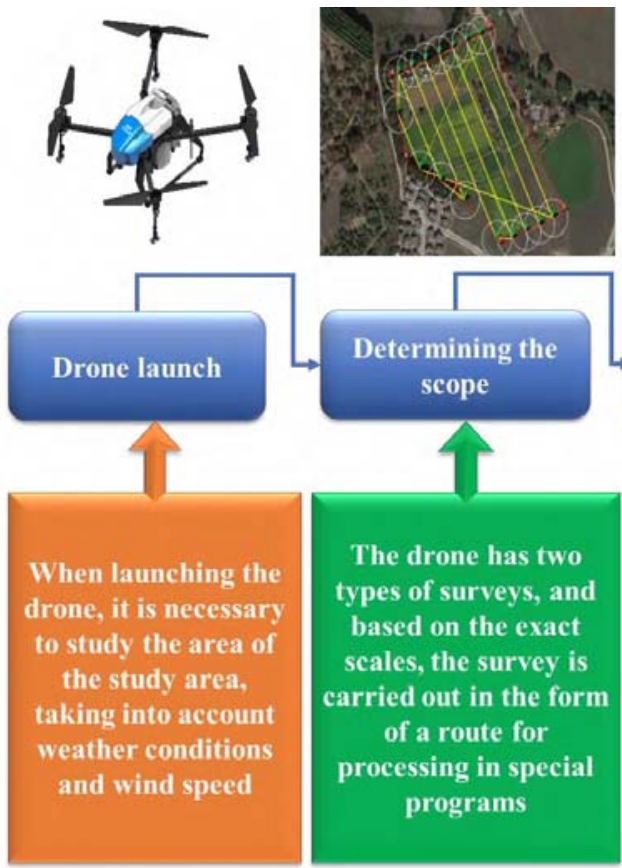

The drone has two types of surveys, and based on the exact scales, the survey is carried out in the form of a route for processing in special programs
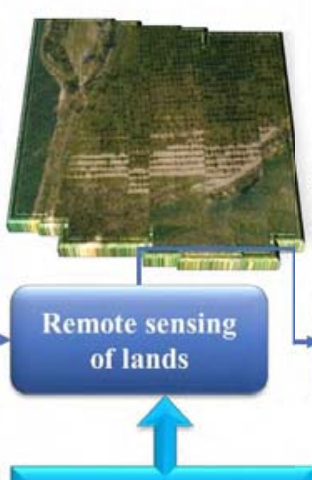

When sounding lands at a distance, the duration of the survey and the power consumption, which will be carried out in the designated area, are taken into account
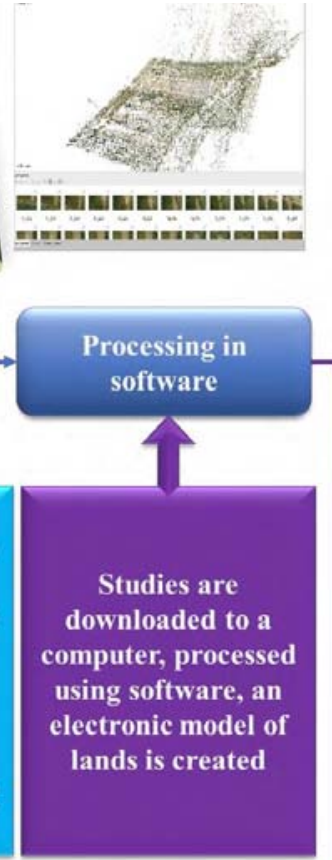

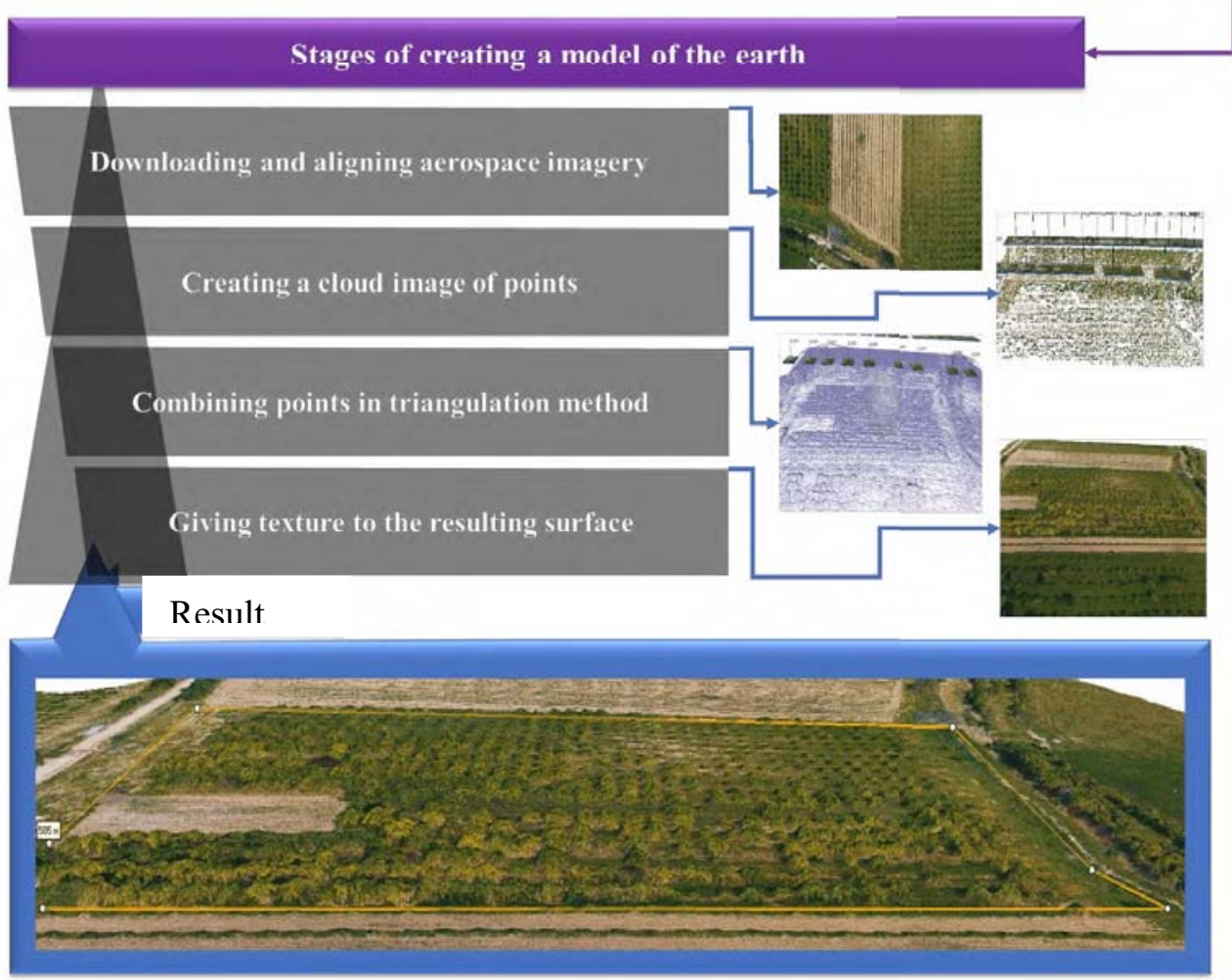

Fig. 4. Mechanism of monitoring of agricultural land and creation of map database. 
Table 2. Comparative characteristics of processing of average 50 hectares of land using agrodrone, CWS and aircraft.

\begin{tabular}{|c|c|c|c|c|c|}
\hline \multirow{2}{*}{$\#$} & \multirow{2}{*}{ Main criterion } & \multirow{2}{*}{ Unit } & \multicolumn{3}{|c|}{ Processing aggregates } \\
\cline { 4 - 6 } & & & Agrodrone & CWS & Aircraft \\
\hline 1 & Processing time & hour & 8 & 50 & 2 \\
\hline 2 & Processing costs & UZS & 900,000 & $1,650,000$ & $4,450,000$ \\
\hline 3 & Number of workers involved & - & 2 & 1 & 3 \\
\hline
\end{tabular}

Details, consideration of land category locally, decrypting in the camera mode was performed $70-80 \%$ accurately based on the satellite images (Fig. 5).

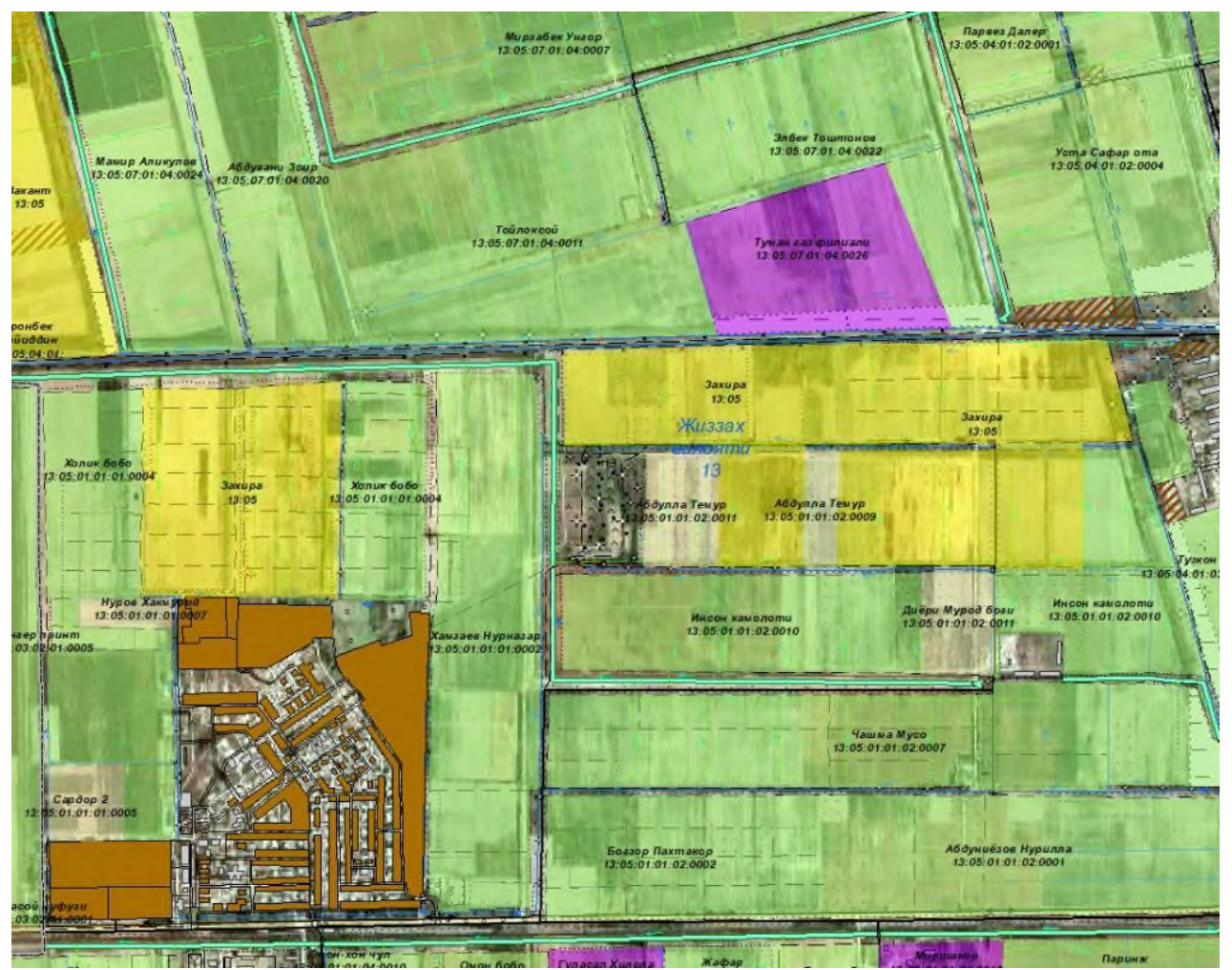

Fig. 5. Details based on the information from satellite images and digital map with the land categories.

The reduction of work has been reached to be carried out on details (roads, ditches, construction sites, canals) that change after the spatial imaging process by means of appropriate measuring instruments in the order established on photomaps (Fig. 6)[1, 4].

There have been changes made of the digital maps of Pakhtakor and Dustlik districts of Jizzakh province using the satellite images in the scale 1:10000, and inserted all the details of changes in the area. 


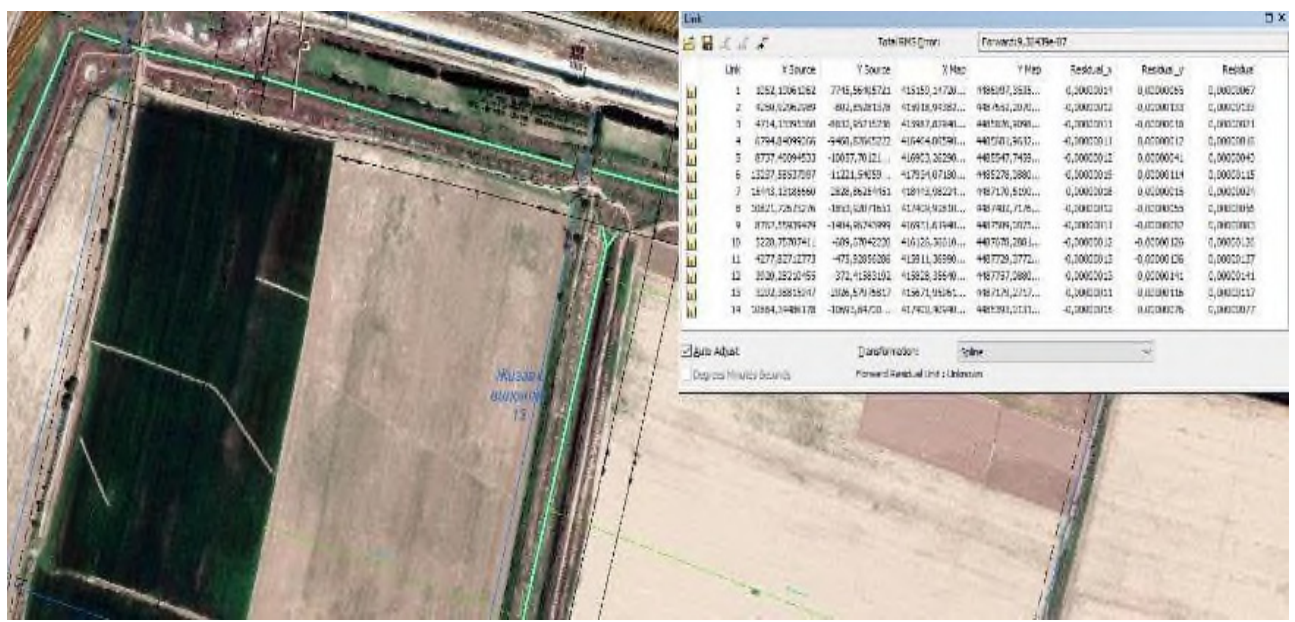

Fig. 6. Geospatial bonding of the images and renewal of the details.

\section{Conclusions}

As a result of the research, the following features of the unmanned aircraft were studied and the necessary recommendations were given:

- Taking planned topographic aerial photos in the scale 1:1,000-1:10,000 for creation and renewing the topographic maps;

- Taking aerial photos for remote detection of technical condition of engineering structures and infrastructure objects (industrial areas, power transmission lines, highways and railways, pipelines supplying oil, gas and other products);

- Aerial photography for the purpose of conducting various types of land monitoring;

- Aerial photography under the influence of heat and low-spectrum rays;

- New aerial photography by means of lightning within view (border).

Based on the above, aerial photos were taken in Dustlik district of Jizzakh province by means of a remote control device to monitor agricultural land and update an electronic digital map at a scale of 1:10,000. Besides, was developed a mechanism for monitoring agricultural land and creating a cartographic base.

\section{References}

1. A. Inamov, I. Ruziev, S. Nurjanov, IOP Conf. Ser.: Mater. Sci. Eng., 030(1), 012112 (2021)

2. Z. Mamatkulov, J. Rashidov, G. Eshchanova, M. Berdiev, Z. Abdurakhmonov,IOP Conf. Ser.: Earth Environ. Sci., 614(1), 012086 (2020)

3. V. Nilipovskiy, A. Inamov, International Multidisciplinary Scientific Geo-Conference Surveying Geology and Mining Ecology Management, 343-350 (2020)

4. K. Khakimova, I. Musaev, A. Khamraliev, E3S Web Conf., 227, 02003 (2021)

5. B. B. Xakimov, A. N. Inamov, B. A. Allanazarov, International Journal of Advanced Research in Science, Engineering and Technology, 6(11), 11538-11543 (2019)

6. D. W. Allen, Getting to know ArcGIS model builder, 380 (ESRI Press, California, 2011)

7. T. Dietz, E. A. Rosa, Frontiers in Ecology and Environment, 5(1), 13-18 (2007) 
8. B. Sh. Matyakubov, Z. J. Mamatkulov, R. K. Oymatov, U. N. Komilov, G. E. Eshchanova, InterCarto, InterGIS, 26, 229-239 (2020)

9. M. Lehoczky, Z. Abdurakhmonov, E3S Web Conf., 227, 04001 (2021)

10. M. Liu, Y. Hu, Y. Chang, X. He, W. Zhang, Environmental Management, 43(5), 899907 (2009)

11. D. Niyogi, R. Mahmood, J. O. Adegoke, Boundary Layer Meterology, 133(3), 297-298 (2009)

12. Z. Mamatkulov, E. Safarov, R. Oymatov, I. Abdurahmanov, M. Rajapbaev, E3S Web Conf., 227, 03001 (2021)

13. S. S. Rao, International Journal of Information Management, 28(6), 474-482 (2008)

14. C. S. Reddy, A. Roy, Research Journal of Environmental Science, 2(2), 108-115 (2007)

15. B. Alikhanov, S. Alikhanova, R. Oymatov, Z. Fayzullaev, A. Pulatov, IOP Conf. Ser.: Mater. Scie. and Eng., 883(1), 012088 (2020)

16. Y. Ten, R. Oymatov, K. Khayitov, G. Saydalieva, U. Nulloev, I. Nematov, E3S Web Conf., 227, 04004 (2021)

17. I. Aslanov, S. Khasanov, Y. Khudaybergenov, M. Groll, Ch. Opp, F. Li, E. Ramirez Del-Valle, E3S Web Conf., 227, 02005 (2021)

18. Y. Peng, F. Li, N. Xu, R. Kulmatov, K. Gao, G. Wang, Y. Zhang, Y. Qiao, Y. Li, H. Yang, S. Hao, Q. Li, S. Khasanov, Chinese Journal of Eco-Agriculture, 29(2), 312-324 (2021) 